\title{
Incorporation of compound inflorescences and selection of high-yielding progenies in cowpea
}

\author{
Karla Annielle da Silva Bernardo(1), Francisco Rodrigues Freire Filho(2), Valdenir Queiroz Ribeiro(3), \\ Paulo Fernando de Melo Jorge Vieira ${ }^{(3)}$ Ângela Celis de Almeida Lopes ${ }^{(1)}$ and Rosana Mendes de Moura Oliveira ${ }^{(1)}$ \\ (1)Universidade Federal do Piauí, Campus da Socopo, CEP 64049-550 Teresina, PI, Brazil. E-mail: karla-anny@hotmail.com, \\ acalopes@ufpi.edu.br, rosanamendes.moura@gmail.com ${ }^{(2)}$ Embrapa Amazônia Oriental, Travessa Dr. Enéas Pinheiro, s/no, Marco,

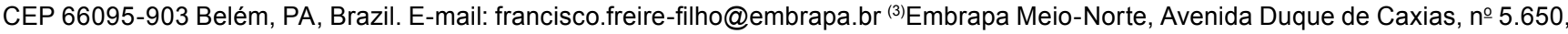 \\ Buenos Aires, CEP 64008-780 Teresina, PI, Brazil. E-mail: valdenir.queiroz@embrapa.br, paulofernando.vieira@embrapa.br
}

\begin{abstract}
The objective of this work was to obtain cowpea (Vigna unguiculata) progenies with compound inflorescences, short peduncles, early cycle, good plant architecture, and high-yielding potential. The initial genetic material consisted of $453 \mathrm{~F}_{2: 3}$ progenies, selected from ten crosses and evaluated using Federer's augmented block design, with two controls. Of these, 60 progenies from the $\mathrm{F}_{4: 5}$ and $\mathrm{F}_{4: 6}$ generations were selected and assessed in two consecutive experiments, both in a 8x8 lattice design with four controls and four replicates. Early selection was efficient at fixing the evaluated traits. A wide genetic variability was detected among and within progenies. The estimated and obtained heritability and genetic gains in the $\mathrm{F}_{4: 5}$ and $\mathrm{F}_{4: 6}$ progenies indicate the possibility of selection of early progenies with short peduncles, compound inflorescences, and productivity similar to or greater than that of the commercial cultivars used as controls.
\end{abstract}

Index terms: Vigna unguiculata, breeding, genetic variability, heritability, quantitative genetics.

\section{Incorporação da inflorescência composta e seleção de progênies produtivas em feijão-caupi}

\begin{abstract}
Resumo - O objetivo deste trabalho foi obter progênies de feijão-caupi (Vigna unguiculata) com inflorescência composta, pedúnculo curto, ciclo precoce, boa arquitetura de planta e alto potencial produtivo. $\mathrm{O}$ material genético inicial constituiu-se de 453 progênies $\mathrm{F}_{2: 3}$, selecionadas a partir de dez cruzamentos e avaliadas em delineamento de blocos aumentados de Federer, com duas testemunhas. Dessas, selecionaram-se 60 progênies das gerações $\mathrm{F}_{4: 5}$ e $\mathrm{F}_{4: 6}$, que foram analisadas em dois experimentos sucessivos, ambos em delineamento látice $8 \times 8$, com quatro testemunhas e quatro repetições. A seleção precoce foi eficiente para fixação dos caracteres avaliados. Detectou-se ampla variabilidade genética entre e dentro das progênies. As herdabilidades e os ganhos genéticos estimados e realizados nas progênies $\mathrm{F}_{4: 5}$ e $\mathrm{F}_{4: 6}$ indicam a possibilidade de seleção de progênies precoces, com comprimento de pedúnculo curto, inflorescência composta e produtividade igual ou superior à das cultivares comerciais utilizadas como testemunhas.
\end{abstract}

Termos para indexação: Vigna unguiculata, melhoramento genético, variabilidade genética, herdabilidade, genética quantitativa.

\section{Introduction}

Cowpea [Vigna unguiculata (L.) Walp.] is a widely adapted legume grown in tropical and subtropical regions. The species is cultivated in 97 countries, at a higher or lower scale (Freire Filho, 2011). However, the Food and Agriculture Organization (FAO) only accounts for the production of 39 countries, and does not include, for example, Brazil and India, which are also great producers and consumers (FAO, 2015).

In Brazil, cowpea is mainly grown in the Northern, Northeastern, and Central-West regions. In the
Central-West, cowpea is incorporated in productive arrangements as a second crop after soybean [Glycine $\max$ (L.) Merr.] and rice (Oryza sativa L.), and, sometimes, as the main crop (Freire Filho, 2011). In some states of those regions, common bean (Phaseolus vulgaris L.) and cowpea are grown in the same farm. Possibly, for this reason, the Systematic Survey of Agricultural Production of Instituto Brasileiro de Geografia e Estatística (IBGE, 2018) publishes data of these two species together. Therefore, the actual contribution of cowpea for total bean production is still 
unknown (Freire Filho, 2011); however, it is estimated that the species accounts for $14 \%$ of the production in the country (Freire Filho et al., 2017).

From 2010 to 2014, the average farmed area was $1,130,931 \mathrm{ha}$, the average production was 451,010 metric tons, and the average yield was $399 \mathrm{~kg} \mathrm{ha}^{-1}$ for cowpea (Freire Filho et al., 2017). However, this yield is considered low and is why the increase of this trait is one of the greatest challenges for breeding.

All annual legumes with high-yielding potential have compound inflorescences arranged in racemes, such as soybean (Hartung et al., 1981), common bean (Teixeira et al., 1999; Kelly, 2001), and chickpea (Cicer arietinum L.) (Gaur \& Gour, 2002). However, cowpea cultivars released in the Brazilian market have simple inflorescences, with no exception, although there are records of this species having compound inflorescences worldwide (Araújo et al., 1981; Fawole \& Afolabe, 1983; Sen \& Bowal, 1961) - a cultivar with this trait, for example, was released in Nigeria (Fawole et al., 1985).

In Brazil, materials with compound inflorescences have been cataloged in the state of Ceará, in 1974, and in the state of Piauí in 1978 (Freire Filho, 2011). Araújo et al. (1981) described these inflorescences, which can produce from four to eight pods each.

Compound inflorescences in cowpea is a trait of easy fixation, since its presence is conditioned by recessive monogenic inheritance (Fawole \& Afolabe, 1983; Machado et al., 2007). Moreover, it is a trait of easy identification, which facilitates selection at an early generation (Fehr, 1987). According to Sousa et al. (2015), additive gene action is the effect of greater relevance in the genetic control of traits related to inflorescences, such as length of peduncles, total number of peduncles per plant, and number of peduncles with pods.

Current breeding programs aim at improving the high-yielding genetic potential of cowpea, especially through the incorporation of resistance to pests and diseases; tolerance to drought, heat, and salinity; reduction of the crop cycle; and improvement of yield and its components. A promising alternative, which has not been properly explored yet, is the improvement of yield and its components by improving plant architecture and its component traits. Sousa et al. (2016) found that the number of pods per plant and yield per plant do not differ significantly between simple and compound inflorescences, but that pod number is usually higher in compound inflorescences. Therefore, incorporating compound inflorescences in commercial cultivars is rather promising to improve the high-yielding potential of the species.

The objective of this work was to obtain cowpea progenies with compound inflorescences, short peduncles, early cycle, good plant architecture, and high-yielding potential.

\section{Materials and Methods}

The trials were conducted in the experimental field of Embrapa Meio-Norte, located in the municipality of Teresina, in the state of Piauí, Brazil $\left(05^{\circ} 5^{\prime} \mathrm{S}, 42^{\circ} 8^{\prime} \mathrm{W}\right.$, at an altitude of $72 \mathrm{~m}$ ). In the first cycle of crosses, the parents were: the Cacheado-roxo accession, which is semi-prostrate, with a medium cycle and compound inflorescences, obtained from Embrapa Meio-Norte; and the AU94-MOB-816 line, which is erect, with an early cycle and simple inflorescences, from Auburn University, AL, USA. In the second cycle of crosses, the used parents were seven lines with compound inflorescences selected from the previous cycle, crossed with the following two erect lines, with an early cycle and simple inflorescences: TE97-309G-9 and $F_{4} R_{1}$ [(BRS Novaera $x$ TE 97-309G-9) x BRS Novaera], totaling ten crosses.

Early selection for compound inflorescences started in generation $F_{2}$. Initially, a total of 453 individual plants with compound inflorescences were selected; after visual evaluation, they were reduced to 414 $\mathrm{F}_{2: 3}$ progenies. To these progenies, 26 lines with simple inflorescences were added as a reference. The progenies were evaluated using Federer's augmented block design, with 440 regular treatments and 2 common treatments, represented by the BRS Guariba and BRS Cauamé cultivars. Then, 153 progenies were selected and, from these, 432 individual plants. These plants formed $432 \mathrm{~F}_{3: 4}$ progenies, all with compound inflorescences. In this case, the augmented block design was also used; the 432 progenies were the regular treatments; and the BRS Guariba, BRS Cauamé, BRS Novaera, and BRS Tumucumaque cultivars were the common treatments. In both of these experiments, each plot had 2-m long rows with a $0.80-\mathrm{m}$ spacing between rows and a $0.20-\mathrm{m}$ spacing between plants in a row; one plant was sown per hole. In the trial with 
$\mathrm{F}_{2: 3}$ progenies, the following traits were evaluated: number of days to flowering (NDF), number of days to maturity (NDM), and dry grain yield per plot (GYPP). In the trial with $\mathrm{F}_{3: 4}$ progenies, in addition to these three traits, number of seeds per pod (SPP) and 100seed weight (100SW) were also assessed.

In the trial with $\mathrm{F}_{3: 4}$ progenies, 60 progenies were selected and used in two consecutive trials, originating the $\mathrm{F}_{4: 5}$ and $\mathrm{F}_{4: 6}$ progenies; the treatment consisted of 60 progenies and four controls - the BRS Guariba, BRS Novaera, BRS Cauamé, and Bico-de-Ouro cultivars. Both trials used an $8 \times 8$ lattice design, with four replicates. The plots had $3.0-\mathrm{m}$ long rows, with $0.80 \mathrm{~m}$ between rows and $0.15 \mathrm{~m}$ between plants in a row, also with one plant sown per hole. In both experiments, the following traits were evaluated: NDF, NDM, pod length (POL), SPP, 100SW, length of floral peduncle (LFP), number of peduncles with pods per plant (NPPL), average number of pods per peduncle (NPPE), and GYPP.

The trials with $\mathrm{F}_{2: 3}$ and $\mathrm{F}_{3: 4}$ progenies, carried out in Federer's augmented block design, were analyzed according to Zimmermann (2014), using the equation: $Y_{i j}=m+t_{i}+b_{j}+e_{i j}$, where $Y_{i j}$ is the observation of the $i^{\text {th }}$ treatment in the $\mathrm{j}^{\text {th }}$ block, with $\mathrm{j}=1,2, \ldots, \mathrm{b} ; \mathrm{I}=1,2, \ldots, \mathrm{p}, \mathrm{p}+1, \mathrm{p}+2, \ldots$, $p+t$, where $p$ is the number of progenies or regular treatments, $t$ is the number of controls, and $\mathrm{p}+\mathrm{t}=\mathrm{v}$ is the total number of treatments; $m$ is the general mean; $t_{i}$ is the effect of the $i^{\text {th }}$ treatment, with $I=1,2$, $\ldots, p, p+1, p+2, \ldots, p+t ; b_{j}$ is the effect of the $j^{\text {th }}$ block, with $\mathrm{j}=1,2, \ldots, \mathrm{b}$; and $\mathrm{e}_{\mathrm{ij}}$ is the random effect normally distributed, $\mathrm{N}\left(0, \sigma^{2}\right)$, and independent.

The individual analysis of the trials in the $8 \times 8$ lattice design in $\mathrm{F}_{4: 5}$ and $\mathrm{F}_{4: 6}$ was performed according to Pimentel-Gomes \& Garcia (2002), using the mathematical model: $\quad \mathrm{Y}_{\mathrm{ijk}}=\mathrm{m}+\mathrm{t}_{\mathrm{i}}+\mathrm{r}_{\mathrm{j}}+\mathrm{b}_{\mathrm{k}(\mathrm{j})}+\mathrm{e}_{\mathrm{ijk}}$, where $Y_{i j k}$ is the value observed in treatment $i$, block $\mathrm{k}$, replicate $\mathrm{j} ; \mathrm{m}$ is the general mean; $\mathrm{t}_{\mathrm{i}}$ is the effect of treatment $i$, with $i=1,2, \ldots, 64 ; r_{j}$ is the effect of replicate $\mathrm{j}$, with $\mathrm{j}=1,4 ; \mathrm{b}_{\mathrm{k}(\mathrm{j})}$ is the effect of block $\mathrm{k}$ in replicate $\mathrm{j}$, with $\mathrm{k}=1,2, \ldots, 8$; and $\mathrm{e}_{\mathrm{ijk}}$ is the experimental error.

The experiments were subjected to a joint analysis, as described by Ramalho et al. (2012b). Specifically for the joint analysis of the trials, adjusted means were adopted, according to the following model: $\mathrm{Y}_{\mathrm{ija}}=\mathrm{m}+\mathrm{t}_{\mathrm{i}}+\mathrm{l}_{\mathrm{a}}+(\mathrm{tl})_{\mathrm{ia}}+\mathrm{e}_{\mathrm{ija}}$, where $\mathrm{Y}_{\mathrm{ija}}$ is the observed value of treatment $i$ in location $a ; m$ is the general mean; $t_{i}$ is the effect of treatment $i$, with $i=1,2, \ldots$, $64 ; 1_{\mathrm{a}}$ is the effect of location a, with $\mathrm{a}=1,2 ;(\mathrm{tl})_{\mathrm{ia}}$ is the effect of the interaction between treatment $i$ and location $\mathrm{a}$; and $\mathrm{e}_{\mathrm{ija}}$ is the mean experimental error. The analyses of individual and joint variances were carried out using the SAS software (SAS Institute Inc., Cary, NC, USA).

The genetic parameters were estimated using the data obtained based on the joint analysis of the trials with $\mathrm{F}_{4: 5}$ and $\mathrm{F}_{4: 6}$ progenies.

Phenotypic variance was determined by: $\mathrm{Vp}=\mathrm{QMT} / \mathrm{re}$, where $\mathrm{V}_{\mathrm{p}}$ corresponds to the phenotypic variance; QMT is the mean square of the regular treatments; $r$ is the number of replicates; and $e$ is the number of trials.

For the joint analysis of progenies, the genetic variance component between means was estimated by: $\mathrm{h}^{2}=\mathrm{V}_{\mathrm{g}} /(\mathrm{QMT} / \mathrm{re})$, where $\mathrm{V}_{\mathrm{g}}$ corresponds to the genetic variance; QMT is the mean square of the regular treatments; QMR is the mean square of the residue; $r$ is number of replicates; and $\mathrm{e}$ is the number of trials.

Since the interaction treatment versus trial was significant, QMR was replaced by the mean square of the interaction (QMT x E) according to PimentelGomes (2009) and Ramalho et al. (2012b).

The coefficient of estimated heritability between the means used for the joint analysis of the evaluated progenies was obtained according to Ramalho et al. (2012a) and Cruz et al. (2012), by: $h^{2}=V_{g} /($ QMT/re), where $h^{2}$ is the coefficient of estimated heritability; $\mathrm{Vg}$ is the genetic variance; QMT is the mean square of the regular treatment; $r$ is number of replicates; and $e$ is the number of trials.

The coefficient of obtained heritability $\left(\mathrm{h}_{\mathrm{r}}^{2}\right)$ was calculated based on the performance of progenies in the Fi and Fj generations, with the following formula proposed by Fehr (1987) and adapted by Ramalho et al. (2012a):

$$
\mathrm{h}_{\mathrm{r}}^{2}=\frac{\left(\mathrm{M}_{\mathrm{sj}}-\mathrm{M}_{\mathrm{gj}}\right) / \mathrm{M}_{\mathrm{gj}}}{\left(\mathrm{M}_{\mathrm{si}}-\mathrm{M}_{\mathrm{gi}}\right) / \mathrm{M}_{\mathrm{gi}}}
$$

where $h_{r}{ }^{2}$ is the coefficient of obtained heritability; $\mathrm{M}_{\mathrm{sj}}$ is the mean in generation $\mathrm{Fj}\left(\mathrm{F}_{4: 6}\right)$ of the progenies selected in $\mathrm{Fi}\left(\mathrm{F}_{4: 5}\right) ; \mathrm{M}_{\mathrm{gj}}$ is the general mean of progenies in generation $\mathrm{Fj} ; \mathrm{M}_{\mathrm{si}}$ is the mean of progenies selected in generation $\mathrm{Fi}$; and $\mathrm{M}_{\mathrm{gi}}$ is the general mean of progenies in generation Fi. 
Genetic gain was estimated according to Frey \& Horner (1955), by: $\mathrm{GS}_{\mathrm{r}}=\left(\mathrm{M}_{\mathrm{sj}}-\mathrm{M}_{\mathrm{gi}}\right)$, where $\mathrm{GS}_{\mathrm{r}}$ is the genetic gain obtained with selection; $\mathrm{M}_{\mathrm{sj}}$ is the mean obtained in generation $\mathrm{Fj}\left(\mathrm{F}_{4: 6}\right)$ of the genotypes selected in generation $\mathrm{Fi}\left(\mathrm{F}_{4: 5}\right)$; and $\mathrm{M}_{\mathrm{gj}}$ is the general mean of genotypes in generation Fi.

All statistical analyses were carried out using the Programa Genes (2013) and the SAS (SAS Institute Inc., Cary, NC, USA) software.

\section{Results and Discussion}

The analyses of variance of the $F_{2: 3}$ and $F_{3: 4}$ generations are shown in Table 1 . In the trial with $\mathrm{F}_{2: 3}$ progenies, there were no significant differences among progenies for the evaluated traits. However, compared with the controls, three of the traits, i.e., NDF, NDM and GYPP, differed significantly, indicating genetic differences between progenies and controls. In the first trial, 332 individual plants were selected based on the traits related to plant architecture and cycle. In the trial with $\mathrm{F}_{3: 4}$ progenies, significant differences were observed for all traits, both among progenies and between progenies and controls. In this case, all traits differed significantly among controls, except GYPP. The 60 most promising $F_{3: 4}$ progenies were selected for future trials, based on yield and traits related to plant architecture, such as peduncle length and height, and genetic variability was maintained among crosses.

In the trial with $\mathrm{F}_{4: 5}$ progenies, all assessed traits differed significantly. Among the controls, significant differences were observed for the following traits: NDF, POL, SPP, LFP, 100SW, and NPPL. The variation source "type" showed a significant effect in almost all traits, indicating that there were differences between progenies and controls, except for SPP. In the trial with $\mathrm{F}_{4: 6}$ progenies, the regular treatments showed significant differences in all studied traits, except NPPL. These significant differences both in $\mathrm{F}_{4: 5}$ and $\mathrm{F}_{4: 6}$ confirm the existence of genetic variability among progenies. The common treatments also differed significantly regarding most traits; the exceptions were POL, SPP, and NPPL.

Significant differences were observed for the effect of "type" for almost all traits, except for SPP and NPPL, indicating progenies and controls differed regarding

Table 1. Analysis of variance of trials with $\mathrm{F}_{2: 3}$ and $\mathrm{F}_{3: 4}$ progenies of cowpea (Vigna unguiculata) regarding the traits number of days to flowering (NDF), number of days to maturity (NDM), pod length (POL), number of seeds per pod (SPP), 100-seed weight (100SW), and dry grain yield per plot (GYPP) in 2013.

\begin{tabular}{|c|c|c|c|c|c|c|c|}
\hline \multirow{2}{*}{$\begin{array}{l}\text { Source of } \\
\text { variation }\end{array}$} & \multirow{2}{*}{$\begin{array}{c}\text { Degree of } \\
\text { freedom }\end{array}$} & \multicolumn{6}{|c|}{ Mean squares } \\
\hline & & $\begin{array}{l}\mathrm{NDF}^{(1)} \\
\text { (day) }\end{array}$ & $\begin{array}{l}\mathrm{NDM}^{(1)} \\
\text { (day) }\end{array}$ & $\begin{array}{l}\text { POL } \\
(\mathrm{cm})\end{array}$ & SPP & $\begin{array}{c}100 \mathrm{SW} \\
(\mathrm{g})\end{array}$ & $\begin{array}{c}\text { GYPP } \\
\left(\text { g per } 1.6 \mathrm{~m}^{2}\right)\end{array}$ \\
\hline & & \multicolumn{6}{|c|}{$\mathrm{F}_{2: 3}$ generation } \\
\hline Block (ig.Trat). & 9 & $1.836^{* *}$ & $0.3063 * *$ & - & - & - & $15,779.24 * *$ \\
\hline Treatment (aj.) & 344 & $0.0720^{\mathrm{ns}}$ & $0.0177^{\mathrm{ns}}$ & - & - & - & $4,425.59^{\text {ns }}$ \\
\hline Progeny (P) & 342 & $0.0566^{\mathrm{ns}}$ & $0.0156^{\mathrm{ns}}$ & - & - & - & $4,272.09^{\text {ns }}$ \\
\hline Control (C) & 1 & $0.1561^{\mathrm{ns}}$ & $0.0199^{\mathrm{ns}}$ & - & - & - & $361.42^{\mathrm{ns}}$ \\
\hline P vs. C & 1 & $5.266^{* *}$ & $0.7366^{* *}$ & - & - & - & $60,985.58$ \\
\hline Error & 9 & 0.0546 & 0.0587 & - & - & - & $2,894.07$ \\
\hline \multicolumn{2}{|l|}{ Coefficient of variation (\%) } & 3.46 & 3.01 & - & - & - & 27.87 \\
\hline & & \multicolumn{6}{|c|}{$\mathrm{F}_{3: 4}$ generation } \\
\hline Block (ig.Trat). & 11 & $0.3206^{* *}$ & $0.2336 * *$ & $3.2918 * *$ & $0.0934 * *$ & $8.0894 * *$ & $12,844.47 * *$ \\
\hline Treatment (aj.) & 335 & $0.0543 * *$ & $0.0415^{* *}$ & $8.0285^{* *}$ & $0.112 *$ & $7.1294 * *$ & $2,037.82 * *$ \\
\hline Progeny $(\mathrm{P})$ & 331 & $0.0396 * *$ & $0.0241 * *$ & $6.4066^{* *}$ & $0.1082 *$ & $5.8161 * *$ & $1,430.52 * *$ \\
\hline Control (C) & 3 & $0.6324 * *$ & $0.3350 * *$ & $69.7387 * *$ & $0.3658 * *$ & $34.0341 * *$ & $799.41^{\mathrm{ns}}$ \\
\hline P vs. C & 1 & $3.1926^{* *}$ & $4.9387 * *$ & $359.7565 * *$ & $0.5924 * *$ & $361.1486 * *$ & $206,767.84 * *$ \\
\hline Error & 33 & 0.0211 & 0.0058 & 0.2927 & 0.0575 & 0.5158 & 597.46 \\
\hline Coefficient of variation $(\%)$ & & 2.29 & 0.99 & 3.10 & 7.07 & 4.42 & 24.41 \\
\hline
\end{tabular}

${ }^{(1)}$ Data transformed into $\sqrt{\mathrm{x}}$. * and $* *$ Significant at $0.01<\mathrm{p} \leq 0.05$ and $\mathrm{p} \leq 0.01$, respectively. ${ }^{\mathrm{n}}$ Nonsignificant by the F-test, at $5 \%$ probability. 
most of the studied traits (Table 2). The coefficients of variation in both trials showed good experimental accuracy and were lower than those obtained by Cruzio (2014), Donça (2012), and Oliveira et al. (2016), when studying the NDF, POL, SPP, 100SW, and GYPP traits in progenies with simple inflorescences.

The joint analysis of the trials with $\mathrm{F}_{4: 5}$ and $\mathrm{F}_{4: 6}$ progenies, using adjusted means with recovery of intrablock information, is shown in Table 3. It was observed that the regular treatments differed significantly regarding all traits, except NPPL, confirming the variability detected in individual analyses and indicating that this trait was not affected by the type of plant inflorescence in the crosses. This result is an indicative that there was no genetic variability in NPPL among the parents used in the

Table 2. Summary of the individual analysis of variance corresponding to 60 cowpea (Vigna unguiculata) progenies and to four controls from the $\mathrm{F}_{4: 5}$ and $\mathrm{F}_{4: 6}$ progenies regarding the traits number of days to flowering (NDF), number of days to maturity (NDM), pod length (POL), number of seeds per pod (SPP), 100-seed weight (100SW), length of floral peduncle (LFP), number of peduncles with pods per plant (NPPL), average number of pods per peduncle (NPPE), and dry grain yield per plot (GYPP) in 2013 and 2014.

\begin{tabular}{|c|c|c|c|c|c|c|c|c|c|c|}
\hline \multirow{2}{*}{$\begin{array}{l}\text { Source of } \\
\text { variation }\end{array}$} & \multirow{2}{*}{$\begin{array}{c}\text { Degree } \\
\text { of } \\
\text { freedom }\end{array}$} & \multicolumn{9}{|c|}{ Mean squares } \\
\hline & & $\begin{array}{l}\mathrm{NDF}^{(1)} \\
\text { (day) }\end{array}$ & $\begin{array}{l}\mathrm{NDM}^{(1)} \\
\text { (day) }\end{array}$ & $\begin{array}{l}\text { POL } \\
(\mathrm{cm})\end{array}$ & $\mathrm{SPP}^{(1)}$ & $\begin{array}{c}100 \mathrm{SW} \\
(\mathrm{g})\end{array}$ & $\begin{array}{l}\text { LFP } \\
(\mathrm{cm})\end{array}$ & NPPL ${ }^{(1)}$ & $\mathrm{NPPE}^{(1)}$ & $\begin{array}{c}\text { GYPP } \\
\left.\text { (g per } 2.4 \mathrm{~m}^{2}\right) \\
\end{array}$ \\
\hline & & \multicolumn{9}{|c|}{$\mathrm{F}_{4: 5}$ progenies } \\
\hline Replicate & 3 & $0.0519^{*}$ & $0.0362 * *$ & $9.8661 * *$ & $0.1959^{*}$ & $2.7067^{\mathrm{ns}}$ & $59.8755^{* *}$ & $4.1793 * *$ & $0.0309^{\mathrm{ns}}$ & $6,1094.270^{* *}$ \\
\hline Block/replicate & 28 & $0.0493^{* *}$ & $0.0125^{\mathrm{ns}}$ & $3.1859 * *$ & $0.1439 * *$ & $7.1818^{* *}$ & $49.6500^{* *}$ & $0.6926^{* *}$ & $0.0426^{* *}$ & $54,192.396^{* *}$ \\
\hline Progeny & 59 & $0.0518^{* *}$ & $0.0453^{* *}$ & $6.5888^{* *}$ & $0.1787 * *$ & $23.5117 * *$ & $73.8430 * *$ & $1.0744^{* *}$ & $0.0378^{* *}$ & $67,053.674^{* *}$ \\
\hline Control & 3 & $0.0675^{* *}$ & $0.0099^{\text {ns }}$ & $5.7141 * *$ & $0.1619 *$ & $19.5721^{* *}$ & $86.3521^{* *}$ & $1.3649^{* *}$ & $0.0309^{\mathrm{ns}}$ & $4,430.583^{\mathrm{ns}}$ \\
\hline Type & 1 & $0.9418^{* *}$ & $0.5838^{* *}$ & $46.3086^{* *}$ & $0.0027^{\mathrm{ns}}$ & $190.9017 * *$ & $224.0069^{* *}$ & $0.2279^{*}$ & $0.7818^{* *}$ & $175,954.815^{* *}$ \\
\hline$\underline{\text { Residue }}$ & 161 & 0.0138 & 0.0094 & 1.1337 & 0.0514 & 1.8917 & 6.9244 & 0.2275 & 0.0132 & $5,255.784$ \\
\hline \multirow[t]{2}{*}{$\mathrm{CV}(\%)$} & & 1.88 & 1.27 & 5.81 & 6.49 & 7.83 & 6.11 & 14.33 & 7.62 & 14.27 \\
\hline & & \multicolumn{9}{|c|}{$\mathrm{F}_{4: 6}$ progenies } \\
\hline Replicate & 3 & $0.0119 * *$ & $0.0058^{*}$ & $3.0735^{*}$ & $0.2722 * *$ & $7.3388^{*}$ & $20.6026^{\mathrm{ns}}$ & $2.6851^{* *}$ & $0.1081^{* *}$ & $25,547.5666^{* *}$ \\
\hline Block/Replicate & 28 & $0.0077 * *$ & $0.0026^{*}$ & $5.1894 * *$ & $0.1294 * *$ & $9.9225^{* *}$ & $58.0756^{* *}$ & $0.4469 * *$ & $0.0461^{* *}$ & $15,663.6282 * *$ \\
\hline Progeny & 59 & $0.0156^{* *}$ & $0.0069 * *$ & $5.4478 * *$ & $0.2672 * *$ & $17.1761^{* *}$ & $60.1348 * *$ & $0.3661^{\mathrm{ns}}$ & $0.0385^{* *}$ & $6,181.2639 * *$ \\
\hline Control & 3 & $0.0329 * *$ & $0.0242 * *$ & $0.2445^{\mathrm{ns}}$ & $0.0246^{\mathrm{ns}}$ & $17.6277^{* *}$ & $87.5740 * *$ & $0.1367^{\mathrm{ns}}$ & $0.0488^{*}$ & $8,233.9718^{* *}$ \\
\hline Type & 1 & $1.2584^{* *}$ & $0.5436^{* *}$ & $133.8737 * *$ & $0.0317^{\mathrm{ns}}$ & $62.1791^{* *}$ & $92.9862 * *$ & $1.7033^{\mathrm{ns}}$ & $1.8048 * *$ & $20,637.5039 * *$ \\
\hline Residue & 161 & 0.0021 & 0.0015 & 1.2014 & 0.0579 & 2.1998 & 10.9672 & 0.3141 & 0.0155 & $1,241.82$ \\
\hline CV (\%) & & 0.71 & 0.5 & 6.37 & 7.39 & 8.37 & 7.95 & 16.26 & 7.89 & 10.18 \\
\hline
\end{tabular}

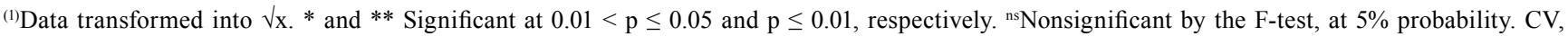
coefficient of variation.

Table 3. Summary of the joint analysis of variance, at plot level, corresponding to 60 cowpea (Vigna unguiculata) progenies regarding the traits number of days to flowering (NDF), number of days to maturity (NDM), pod length (POL), number of seeds per pod (SPP), 100-seed weight (100SW), length of floral peduncle (LFP), number of peduncles with pods per plant (NPPL), average number of pods per peduncle (NPPE), and dry grain yield per plot (GYPP) in 2013 and 2014.

\begin{tabular}{|c|c|c|c|c|c|c|c|c|c|c|}
\hline Source of & Degree of & & & & & Mean squ & res & & & \\
\hline variation & & $\begin{array}{l}\mathrm{NDF}^{(1)} \\
\text { (day) }\end{array}$ & $\begin{array}{c}\mathrm{NDM}^{(1)} \\
\text { (day) }\end{array}$ & $\begin{array}{l}\text { POL } \\
(\mathrm{cm})\end{array}$ & $\mathrm{SPP}^{(1)}$ & $\begin{array}{c}100 \mathrm{SW} \\
(\mathrm{g})\end{array}$ & $\begin{array}{l}\text { LFP } \\
(\mathrm{cm})\end{array}$ & $\mathrm{NPPL}^{(1)}$ & $\mathrm{NPPE}^{(1)}$ & $\begin{array}{c}\text { GYPP } \\
\left(\text { g per } 2.4 \mathrm{~m}^{2}\right)\end{array}$ \\
\hline Experiment (E) & 1 & $5.60517 * *$ & $7.30122 * *$ & $174.124 * *$ & $6.52304 * *$ & $7.2349 * *$ & $256.191 * *$ & $0.89922 * *$ & $0.66543 * *$ & $2,965,369.63 * *$ \\
\hline Progeny $(\mathrm{P})$ & 59 & $0.04717 *$ & $0.03741^{*}$ & $8.229 *$ & $0.2888 *$ & $36.7326^{* *}$ & $114.313 * *$ & $0.85918^{\mathrm{ns}}$ & $0.04561 *$ & $51,310.28 *$ \\
\hline P vs. E & 59 & $0.02918 * *$ & $0.02179 * *$ & $5.317 * *$ & $0.2288 * *$ & $9.5643^{* *}$ & $40.999 * *$ & $0.79135 * *$ & $0.04326^{*}$ & $29,012.68 * *$ \\
\hline Mean error & 126 & 0.00798 & 0.00548 & 1.16754 & 0.0547 & 2.0458 & 8.946 & 0.27086 & 0.01436 & $3,248.8$ \\
\hline $\mathrm{CV}(\%)$ & & 1.34 & 0.95 & 6.55 & 7.09 & 8.86 & 7.52 & 15.4 & 6.65 & 20.17 \\
\hline
\end{tabular}

${ }^{(1)}$ Data transformed into $\sqrt{ } \mathrm{x} . *$ and $* *$ Significant at $0.01<\mathrm{p} \leq 0.05$ and $\mathrm{p} \leq 0.01$, respectively. ${ }^{\mathrm{n}}$ Nonsignificant by the F-test, at $5 \%$ probability. 
crosses. The interaction between regular treatments and experiments was significant for all traits, showing the differentiated behavior of one or more progenies in both experiments. In addition, the values of the coefficient of variation were low for almost all traits, except for GYPP.

The estimates of the genetic parameters obtained from the joint analysis of the trials with the $\mathrm{F}_{4: 5}$ and $\mathrm{F}_{4: 6}$ progenies are listed in Table 4. Heritability estimates ranged from $0.05 \%$ for NPPE to $64 \%$ for LFP, and were lower than those found in individual analyses. The significant interaction between regular treatments and trial, in all traits, possibly contributed to this result. All heritability values were within the confidence interval, indicating good accuracy of estimates. Moreover, the heritability of the traits associated with earliness was higher than that obtained for progenies with simple inflorescences (Cruzio, 2014), but lower than those found in studies with compound inflorescences (Barros et al., 2011; Sousa et al., 2015). The NDF, NDM, LFP, and GYPP traits showed the highest estimates of heritability. These results are very important because these traits are the focus of the selection in the present work, aiming to reduce the expression of NDF, NDM, and LFP, increasing that of GYPP.

The genetic gains obtained with selection ranged from $-0.41 \%$ for NDM to $11.07 \%$ for $100 \mathrm{SW}$, in relation to the general mean of progenies, and from -0.42 to $9.62 \%$, respectively, in relation to the best control. The traits associated with earliness and peduncle length showed negative genetic gain values. These results are important since selection aimed at reducing the expression of these traits. Sousa et al. (2015) highlighted the difficulty in obtaining early genotypes with compound inflorescences. For the second crop in the Central-West region of Brazil, especially in the state of Mato Grosso, it is essential for cowpea cultivars to be early, because they are sown at the end of the wet season. In the present study, the occurrence of transgressive segregation resulted in progenies with compound inflorescences and that are earlier than the earliest parent.

Table 4. Estimates of genetic variance $(\mathrm{Vg})$, phenotypic variance $(\mathrm{Vp})$, coefficient of heritability $\left(\mathrm{h}^{2}\right)$, inferior (LI) and superior limits (LS) of the estimates of heritability, selection differential (DS), genetic gain obtained through direct selection in progenies (GSG), gain obtained through selection in relation to general mean (GS), and gain through selection in relation to the mean of the best control (GSC) for the joint analysis of $60 \mathrm{~F}_{4: 5}$ and $\mathrm{F}_{4: 6}$ progenies of cowpea (Vigna unguiculata) in 2013 and 2014.

\begin{tabular}{|c|c|c|c|c|c|c|c|c|c|}
\hline \multirow[t]{2}{*}{ Parameter $^{(1)}$} & \multicolumn{9}{|c|}{ Traits $^{(2)}$} \\
\hline & $\mathrm{NDF}^{(3)}$ (day) & $\mathrm{NDM}^{(3)}$ (day) & POL $(\mathrm{cm})$ & $\mathrm{SPP}^{(3)}$ & $100 \mathrm{SW}(\mathrm{g})$ & $\mathrm{LFP}(\mathrm{cm})$ & $\mathrm{NPPL}^{(3)}$ & $\mathrm{NPPE}^{(3)}$ & GYPP (g per $2.4 \mathrm{~m}^{2}$ ) \\
\hline $\mathrm{V}_{\mathrm{g}}$ & 0.0023 & 0.002 & 0.364 & 0.0075 & 3.396 & 9.1642 & 0.0085 & 0.0003 & $2,787.2$ \\
\hline $\mathrm{V}_{\mathrm{p}}$ & 0.0059 & 0.0046 & 1.0286 & 0.0361 & 4.5915 & 14.2891 & 0.1073 & 0.0057 & $6,413.785$ \\
\hline$h^{2}$ & 0.38 & 0.42 & 0.35 & 0.21 & 0.74 & 0.64 & 0.08 & 0.05 & 0.43 \\
\hline LI; LS & $(-0.035 ; 0.63)$ & $(0.025 ; 0.65)$ & $(-0.082 ; 0.61)$ & $(-0.33 ; 0.53)$ & $(0.56 ; 0.84)$ & $(0.39 ; 0.78)$ & $(-0.54 ; 0.45)$ & $(-0.58 ; 0.43)$ & $(0.05 ; 0.66)$ \\
\hline DS & -0.0945 & -0.0768 & 1.2602 & 0.2419 & 2.6133 & -4.3563 & 0.4036 & 0.0969 & 96.9209 \\
\hline GSG & -0.0361 & -0.0321 & 0.446 & 0.0503 & 1.9329 & -2.7939 & 0.0319 & 0.005 & 42.1183 \\
\hline GS (\%) & -0.5647 & -0.412 & 2.534 & 1.491 & 11.0715 & -6.5635 & 0.9429 & 0.3194 & 9.9771 \\
\hline GSC (\%) & -0.606 & -0.4234 & 2.3042 & 1.5362 & 9.6238 & -7.8169 & 1.0118 & 0.3764 & 8.5167 \\
\hline MGP & 40.78 & 60.61 & 17.6 & 11.36 & 17.46 & 42.57 & 11.42 & 2.44 & 422.15 \\
\hline MPS & 39.56 & 59.44 & 18.86 & 13.03 & 20.07 & 38.21 & 14.29 & 2.76 & 519.07 \\
\hline MGC & 37.15 & 57.41 & 20.17 & 11.58 & 20.44 & 39.17 & 12.24 & 1.56 & 499.16 \\
\hline $\mathrm{MBC}$ & 35.4 & 57.46 & 19.35 & 10.69 & 20.08 & 35.74 & 9.92 & 1.77 & 494.54 \\
\hline MBP & 38.56 & 58.67 & 19.92 & 14.29 & 24.58 & 36.14 & 16.97 & 3.13 & 595.18 \\
\hline MGT & 40.55 & 60.41 & 17.76 & 11.37 & 17.64 & 42.35 & 11.47 & 2.38 & 426.96 \\
\hline
\end{tabular}

${ }^{(1)}$ MGP, general mean of progenies; MPS, mean of the 15 selected progenies per trait; MGC, general mean of controls; MBC, mean of the best control; MBP, mean of the best progeny; and MGT, general mean of the trial. ${ }^{(2)} \mathrm{NDF}$, number of days to flowering; NDM, number of days to maturity; POL, pod length; SPP, number of seeds per pod; 100SW, 100-seed weight; LFP, length of floral peduncle; NPPL, number of peduncles with pods per plant; NPPE, average number of pods per peduncle; and GYPP, dry grain yield per plot. ${ }^{(3)}$ Data transformed into $\sqrt{ } \mathrm{x}$. 
Estimates of heritability $\left(\mathrm{h}_{\mathrm{r}}{ }_{\mathrm{r}}\right)$ and of the genetic gains obtained with selection $\left(\mathrm{GS}_{\mathrm{r}}\right)$ reflect the actual gains (Table 5). The SPP and 100SW traits exhibited estimates of heritability above $50 \%$, POL and LFP of about 40\%, and NDF, NDM, NPPE, and GYPP of approximately $20 \%$. Cruzio (2014) also reported low estimates for GYPP and high estimates for 100SW when evaluating progenies with simple inflorescences. In the present study, NPPL had the lowest estimate. Although the heritability of this trait was higher in the trial with $\mathrm{F}_{4: 5}$ progenies (0.79), it was lower in the second trial with $\mathrm{F}_{4: 6}$ progenies (0.14), which contributed to the low obtained heritability. The genetic gain with selection showed a variation similar to that of obtained heritability, as expected. The SPP and 100SW traits exhibited estimates of gain above $50 \%$, and POL and LFP above $30 \%$, whereas the other traits had estimates of about $20 \%$, except NPPL. The negative genetic gains for NDF, NDM, and LFP and the positive genetic gains for GYPP, both estimated and obtained, are very important because they are aligned with the requirements of current breeding. These results show that it is possible to achieve yield gains by obtaining and selecting materials with compound inflorescences.

Table 5. Estimated and obtained heritability and genetic gain through selection of the $\mathrm{F}_{4: 5}$ and $\mathrm{F}_{4: 6}$ progenies of cowpea (Vigna unguiculata) in 2013 and 2014.

\begin{tabular}{|c|c|c|c|c|c|c|}
\hline \multirow[t]{3}{*}{ Trait $^{(1)}$} & \multicolumn{3}{|c|}{ Heritability } & \multicolumn{3}{|c|}{ Gain through selection } \\
\hline & \multirow{2}{*}{$\frac{\mathrm{F}_{4: 5}}{\text { Estimated }}$} & \multicolumn{2}{|c|}{$\mathrm{F}_{4: 6}$} & \multirow{2}{*}{$\frac{\mathrm{F}_{4: 5}}{\text { Estimated }}$} & \multicolumn{2}{|c|}{$\mathrm{F}_{4: 6}$} \\
\hline & & Obtained & $\begin{array}{c}\text { Obtained } \\
(\%)\end{array}$ & & Obtained & $\begin{array}{c}\text { Obtained } \\
(\%) \\
\end{array}$ \\
\hline $\mathrm{NDF}$ & 0.73 & 0.14 & 18.95 & -0.1107 & -0.0217 & 19.6 \\
\hline NDM & 0.79 & 0.18 & 22.71 & -0.1013 & -0.0234 & 23.1 \\
\hline POL & 0.83 & 0.33 & 39.86 & 1.3675 & 0.5018 & 36.69 \\
\hline SPP & 0.71 & 0.42 & 58.96 & 0.2008 & 0.1094 & 54.48 \\
\hline 100SW & 0.92 & 0.49 & 53.29 & 2.9897 & 1.6293 & 54.5 \\
\hline LFP & 0.91 & 0.37 & 40.83 & -4.6779 & -1.8399 & 39.33 \\
\hline NPPL & 0.79 & 0.03 & 3.81 & 0.506 & 0.0203 & 4.01 \\
\hline NPPE & 0.65 & 0.11 & 16.91 & 0.0899 & 0.0157 & 17.46 \\
\hline GYPP & 0.92 & 0.21 & 22.79 & 149.1364 & 27.1588 & 18.21 \\
\hline Mean & - & - & 30.9 & - & - & 29.71 \\
\hline
\end{tabular}

(1)NDF, number of days to flowering; NDM, number of days to maturity; POL, pod length; SPP, number of seeds per pod; 100SW, 100-seed weight; LFP, length of floral peduncle; NPPL, number of peduncles with pods per plant; NPPE, average number of pods per peduncle; and GYPP, dry grain yield per plot.

\section{Conclusions}

1. The incorporation of compound inflorescences allows increasing the yielding potential of cowpea (Vigna unguiculata) progenies.

2. Selection in early generation is efficient for selecting cowpea progenies with compound inflorescences.

3. There is wide genetic variability among the studied progenies, with the possibility of gains through selection in all evaluated traits, except number of peduncles per plant.

4. There are selection gains when obtaining early progenies with compound inflorescences, short peduncles, and productivity similar to or greater than that of the commercial cultivars used as controls.

\section{Acknowledgments}

To the employees of Embrapa Meio-Norte, for their valuable cooperation and execution of the experiment; to Coordenação de Aperfeiçoamento de Pessoal de Nível Superior (Capes), for the scholarship grant; and to Conselho Nacional de Desenvolvimento Científico e Tecnológico (CNPq), for funding this study.

\section{References}

ARAÚJO, J.P.P. de; SANTOS, A.A.; CARDOSO, M.J.; WATT, E.E. Nota sobre a ocorrência de uma inflorescência ramificada em caupi Vigna unguiculata (L.) Walp subsp. unguiculata, no Brasil. Revista Ciência Agronômica, v.12, p.187-193, 1981.

BARROS, F.R.; ANUNCIAÇÃO FILHO, C.J. da; ROCHA, M. de M.; NUNES, J.A.R.; SILVA, K.J.D. e; FREIRE FILHO, F.R.; RIBEIRO, V.Q. Potencial genético de progênies de feijãocaupi segregantes quanto ao tipo da inflorescência. Pesquisa Agropecuária Brasileira, v.46, p.182-189, 2011. DOI: 10.1590/ S0100-204X2011000200010.

CRUZ, C.D.; REGAZZI, A.J.; CARNEIRO, P.C.S. Modelos biométricos aplicados ao melhoramento genético. 4.ed. Viçosa: Ed. da UFV, 2012. p.210-235.

CRUZIO, A.S. Eficiência da seleção em geração precoce para tamanho de grão e seu efeito em outros caracteres de feijãocaupi. 2014. 78p. Dissertação (Mestrado) - Universidade Federal do Piauí, Teresina.

DONÇA, M.C.B. Seleção precoce para caracteres dos grãos no melhoramento do feijão-caupi. 2012. 101p. Dissertação (Mestrado) - Universidade Federal de Lavras, Lavras. 
FAO. Food and Agriculture Organization of the United Nations. Faostat: production: crops. Available at: $<$ http://faostat.fao.org/ download/Q/QC/E>. Accessed on: Oct. 242015.

FAWOLE, Y.; AFOLABE, N.O. Genetic control of a branching peduncle mutant of cowpea, Vigna unguiculata (L.) Walp. Journal of Agricultural Science, v.100, p.473-475, 1983. DOI: $10.1017 /$ S0021859600033633.

FAWOLE, Y.; AFOLABE, N.O.; RAJI, J.A. Release of the Ife branched peduncle cowpea. Tropical Grain Legume Bulletin, V.31, p.15-16, 1985.

FEHR, W.R. Principles of cultivar development: theory and technique. New York: Macmillan, 1987. v.1, p.319-327.

FREIRE FILHO, F.R. (Ed.). Feijão-caupi no Brasil: produção, melhoramento genético, avanços e desafios. Teresina: Embrapa Meio-Norte, 2011. 84p.

FREIRE FILHO, F.R.; RIBEIRO, V.Q.; RODRIGUES, J.E.L.F.; VIEIRA, P.F. de M.J. A cultura: aspectos socioeconômicos. In: DOVALE, J.C.; BERTINI, C.; BORÉM, A. (Ed.). Feijão-caupi: do plantio à colheita. Viçosa: Ed. da UFV, 2017. p.9-34.

FREY, K.J.; HORNER, T. Comparison of actual and predicted gains in barley selection experiments. Agronomy Journal, v.47, p.186-188, 1955. DOI: 10.2134/agronj1955.0002196200470004001 $0 \mathrm{x}$.

GAUR, P.M.; GOUR, V.K. A gene producing one to nine flowers per flowering node in chickpea. Euphytica, v.128, p.231-235, 2002. DOI: $10.1023 / \mathrm{A}: 1020845815319$.

HARTUNG, R.C.; SPECHT, J.E.; WILLIAMS, J.H. Modifications of soybean plant architecture by genes for stem growth habit and maturity. Crop Science, v.21, p.51-56, 1981. DOI: 10.2135/ cropsci1981.0011183X002100010015x.

IBGE. Levantamento Sistemático da Produção Agrícola - LSPA. Available at: <https://www.ibge.gov.br/estatisticasnovoportal/economicas/agricultura-e-pecuaria/9201levantamento-sistematico-da-producao-agricola.html $?=\& \mathrm{t}=\mathrm{o}-$ que-e>. Accessed on: Oct. 122018.

KELLY, J.D. Remaking bean plant architecture for efficient production. Advances in Agronomy, v.71, p.109-143, 2001. DOI: 10.1016/S0065-2113(01)71013-9.

MACHADO, C. de F.; FREIRE FILHO, F.R.; RIBEIRO, V.Q.; COSTA, D.S.S.; AMORIM, A.F. de. Herança da inflorescência composta da cultivar de feijão-caupi Cacheado. Ciência e Agrotecnologia, v.31, p.1347-1350, 2007. DOI: 10.1590/S141370542007000500011 .
OLIVEIRA, R.M. de M.; FREIRE FILHO, F.R.; RIBEIRO, V.Q.; LOPES, A.C. de A.; BERNARDO, K.A. da S.; CRUZIO, A.S. Diallel analysis in cowpea aiming at selection for extra-earliness. Crop Breeding and Applied Biotechnology, v.16, p.167-173, 2016. DOI: 10.1590/1984-70332016v16n3a26.

PIMENTEL-GOMES, F. Curso de estatística experimental. 15.ed. Piracicaba: FEALQ, 2009. 451p.

PIMENTEL-GOMES, F.P.; GARCIA, C.H. Estatística aplicada a experimentos agronômicos e florestais: exposição com exemplos e orientações para uso de aplicativos. Piracicaba: FEALQ, 2002. 309p.

PROGRAMA GENES: aplicativo computacional em genética e estatística experimental. Viçosa: Ed. da UFV, 2013. Available at: <www.ufv.br/dbg/genes/genes.htm>. Accessed on: Nov. 222013.

RAMALHO, M.A.P.; ABREU, A. de F.B.; SANTOS, J.B. dos; NUNES, J.A.R. Aplicações da genética quantitativa no melhoramento de plantas autógamas. Lavras: Ed. da UFLA, 2012a. 522p.

RAMALHO, M.A.P.; FERREIRA, D.F.; OLIVEIRA, A.C. de. Experimentação em genética e melhoramento de plantas. 3.ed. Lavras: Ed. da UFLA, 2012b. 328p.

SEN, N.K.; BOWAL, J.G. Genetics of Vigna sinensis (L.) Savi. Genetica, v.32, p.247-266, 1961. DOI: 10.1007/BF01816096.

SOUSA, I. da S.; ANUNCIAÇÃO FILHO, C.J. da; FREIRE FILHO, F.R.; RIBEIRO, V.Q.; VIEIRA, P.F. de M.J. Genética de caracteres do pedúnculo em cruzamentos de feijão-caupi, segregando para inflorescências simples e composta. Teresina: Embrapa Meio-Norte, 2015. 29p. (Embrapa Meio-Norte. Boletim de pesquisa e desenvolvimento, 109).

SOUSA, I. da S.; ANUNCIAÇÃO FILHO, C.J. da; FREIRE FILHO, F.R.; RIBEIRO, V.Q.; VIEIRA, P.F. de M.J. Genética da produtividade em feijão-caupi com infloresencência simples e composta. Teresina: Embrapa Meio-Norte, 2016. 27p. (Embrapa Meio-Norte. Boletim de pesquisa e desenvolvimento, 111).

TEIXEIRA, F.F.; RAMALHO, M.A.P.; ABREU, A. de F.B. Genetic control of plant architecture in the common bean (Phaseolus vulgaris L.). Genetics and Molecular Biology, v.22, p.577-582, 1999. DOI: 10.1590/S1415-47571999000400019.

ZIMMERMANN, F.J.P. Estatística aplicada à pesquisa agrícola. 2.ed. rev. e ampl. Brasília: Embrapa, 2014. 582p.

Received on July 3, 2017 and accepted on December 4, 2017

Pesq. agropec. bras., Brasília, v.53, n.10, p.1150-1157, Oct. 2018 DOI: $10.1590 / \mathrm{S} 0100-204 X 2018001000008$ 